\title{
Clear cell acanthoma of the nipple: another report from Italy
}

\author{
Gianluca Nazzaro ${ }^{1}$
}

DOI: http://dx.doi.org/10.1590/abd1806-4841.20143184

I read in your Journal, with great interest, the paper by Veiga and coworkers ${ }^{1}$ about two cases of clear cell acanthomas located in the nipple area, with histological and immunohistochemical studies. They claim in the discussion, that only five cases had been previously described in the English literature and all affecting Korean women. ${ }^{2,3,4}$ Four of these cases mimicked chronic eczema.

Two new cases were added: the first ones in Brazil and both with clinical appearance resembling chronic eczema.
I reported, in 2012, a similar case in Archives of Dermatology 5 : a young man, suffering from atopic dermatitis since infancy, was treated with topical steroids for months with signs of concentration of this dermatitis in the nipple-area complex. The histology revealed a clear cell acanthoma: the first one described in Europe.

I think that these case series are really important; because they may be considered as another evidence supporting the hypothesis that clear cell acanthoma is a reactive dermatosis, due to chronic inflammation.

Received on 01.10.2013.

Approved by the Advisory Board and accepted for publication on 04.10.2013.

* Work performed at the Dipartimento di Fisiopatologia medico-chirurgica e dei trapianti, Università degli Studi di Milano - Fondazione IRCCS Ca' Granda Ospedale Maggiore Policlinico, Milano

Conflict of interest: None

Financial support: None

MD - Doctor. Dipartimento di Fisiopatologia medico-chirurgica e dei trapianti, Università degli Studi di Milano - Fondazione IRCCS Ca' Granda Ospedale Maggiore Policlinico, Milano

(C)2014 by Anais Brasileiros de Dermatologia

\section{REFERENCES}

1. da Veiga RRG, Barros RS, Santos JEB, Abreu-Junior JMC, Bittencourt MJS, Miranda MFR. Clear cell acanthoma of the areola and nipple: Clinical, histopathological, and immunohistochemical features of two Brazilian cases. An Bras Dermatol. 2013;88(1):84-9.

2. Kim DH, Kim CW, Kang SJ, Kim TY. A case of clear cell acanthoma presenting as nipple eczema. Br J Dermatol. 1999;141:950-1.

3. Um SH, Oh CW. Three cases of clear cell acanthoma on nipple and areola. Korean J Dermatol. 2003;41:85-8.

4. Park SY, Jung JY, Na Jl, Byun HJ, Cho KH. A case of polypoid clear cell acanthoma on the nipple. Ann Dermatol. 2010;22:337-40.

5. Nazzaro G, Coggi A, Gianotti R. A 26-year-old man with an eczematous lesion on the nipple. Arch Dermatol. 2012;148:641-6.

\author{
MAILING ADDRESS: \\ Gianluca Nazzaro \\ Via Pace, 9 - 20122 - Milano, Italy \\ gianluca.nazzaro@gmail.com
}

